\title{
The biology and synthesis of a-hydroxytropolones
}

\author{
Christine Meck, Michael P. D'Erasmo, Danielle R. Hirsch, and Ryan P. Murelli \\ Brooklyn College, City University of New York, Department of Chemistry, 2900 Bedford 4 \\ Avenue, Brooklyn, New York, USA
}

\section{Abstract}

a-Hydroxytropolones are a subclass of the troponoid family of natural products that are of high interest due to their broad biological activity and potential as treatment options for several diseases. Despite this promise, there have been scarce synthetic chemistry-driven optimization studies on the molecules. The following review highlights key developments in the biological studies conducted on a-hydroxytropolones to date, including the few synthetic chemistry-driven optimization studies. In addition, we provide an overview of the methods currently available to access these molecules. This review is intended to serve as a resource for those interested in biological activity of a-hydroxytropolones, and inspire the development of new synthetic methods and strategies that could aid in this pursuit.

a-Hydroxytropolones (aHTs, Figure 1) are a subset of the troponoid family of natural products that have shown a highly diverse range of biological activity. While the suffix a implies the 7 hydroxytropolone tautomeric form, the molecules often undergo tautomerization between the 7 and 3-hydroxytropolone forms. ${ }^{1}$

There are several features that arise due to this contiguous array of oxygen atoms that distinguish them from other troponoid compounds. ${ }^{2}$ Due to resonance stabilization, the acidity of tropolones $\left(\mathrm{p} K_{\mathrm{a}}=\sim 7\right)$ is between that of a phenol $\left(\mathrm{p} K_{\mathrm{a}}=10\right)$ and a carboxylic acid $\left(\mathrm{p} K_{\mathrm{a}}=5\right) .{ }^{3}$ The inductive electron withdrawing nature of the added hydroxyl of aHTs lowers their $\mathrm{p} K_{\mathrm{a} 1}$ to 5.6. ${ }^{4}$ In its monoionic form, the other hydroxyl remains acidic, with calculated $\mathrm{p} K_{\mathrm{a} 2}$ around 7.0, thus giving aHTs significant dianionic character at physiological pH (Scheme 1). ${ }^{5}$ Combined with the high Lewis basicity of the tropolone carbonyl due to the stabilized tropylium ion, ${ }^{6}$ significant negative charges can be localized onto all three of these oxygens, creating a trident-like array of oxygen atoms bearing some negative charge (Scheme 1). Thus, significant differences between these molecules and typical tropolones exist, particularly as it relates to the different mechanisms through which they can chelate to metals. ${ }^{7}$ All of these factors provide aHTs with distinct differences from other tropolones when it comes to their bioactivity.

The following review will discuss the diverse bioactivity that has been demonstrated by aHTs, and some of the preliminary studies that have gone into their optimization for both potency and selectivity. In addition, given the important role that the synthesis of these 
molecules will play in optimizing aHTs for their given function, we will also summarize synthetic strategies that have proven effective in generating these compounds.

\section{Cytotoxicity}

\section{Antifungal activity}

Some of the earliest bioactivity studies on a hydroxytropolones were based upon the knowledge that the extractives of the western red cedar tree, of which the tropolone-based thujaplicins are a major component, had significant antifungal activity. ${ }^{8}$ It is believed that this activity of the extractives are largely responsible for the high durability of the trees, and thus a broad range of studies have gone into understanding this activity at the molecular level. ${ }^{9}$

In 1959, Roff and Whittaker carried out a survey of the antifungal activity of $\beta$ thujaplicinol against several fungi responsible for wood rot. ${ }^{10}$ When tested against brown-rot fungi Poria monticola and Coniophora puteana, $\beta$ thujaplicinol showed comparable activity to the antifungals sodium pentachlorophenate and $\gamma$-thujaplicin (Figure 2), with minimum growth inhibitory (MIC) concentration of $10 \mu \mathrm{M}$. However, when tested against the white-rot fungi Polyporus versicolor, Stereum sanguinolentum, and Phellinus weirii, the compound was significantly less toxic, with MIC values of $800 \mu \mathrm{M}, 330 \mu \mathrm{M}$, and $100 \mu \mathrm{M}$, respectively. In contrast, $\gamma$ thujaplicin was almost ten times more potent against white rot fungi, with minimum growth inhibitor concentrations of $70 \mu \mathrm{M}, 50 \mu \mathrm{M}$, and $50 \mu \mathrm{M}$, respectively. The conclusion drawn from these studies was that, while active, $\beta$-thujaplicinol is likely not a significant contributor to the durability of the western red cedar. Still, as a major component of its extract combined with antifungal activity, $\beta$ thujaplicinol remains of interest in studying the durability of the western red cedar.

In addition to their potential role in protective effects for red cedar, other studies have revealed that $\beta$ thujaplicinol has fungistatic activity against several fungi of the Aspergillus genus, including the pathogenic A. fumigatus. A. fumigatus is a common fungus which is known to cause disease, particularly in patients with compromised immune systems due to AIDS or leukemia. ${ }^{11}$ In one study by Sanders, at concentrations of $35 \mu \mathrm{M}$, the lowest concentration of $\beta$ thujaplicinol tested in a screen against several different fungi, no growth of A. fumigatus was observed at 96 hours. ${ }^{12}$ In experiments run over longer periods of time (4 weeks), roughly twice that concentration was needed to prevent growth. In more recent experiments by researchers at Bristol-Myers, however, aHT showed significantly lower activity against $A$. fumigatus strain IAM2350, with an MIC of $730 \mu \mathrm{M} .{ }^{13}$ Regardless, these studies suggest that the antifungal activity of aHTs might be leveraged for therapeutic purposes, but further studies are clearly needed. However, unlike some other targets that will be discussed, there does not appear to be any advantages of aHTs over tropolones when it comes to their antifungal activity.

\section{Antibacterial activity}

In 1961, Sanders published a survey on the activity of $\beta$ thujaplicinol against 40 different bacteria. ${ }^{12}$ The most susceptible strains were Bacillus megaterium and Sarcina lutea, which showed significant growth inhibition at only $35 \mu \mathrm{M}$. In general, Gram-positive bacteria were 
more likely to be inhibited by $\beta$-thujaplicinol than Gram-negative. In fact, several strains of the Gram-negative bacteria in the Pseudomonas genus, including $P$. aeruginosa, $P$. fluorescens, and $P$. pyocyaneus, showed no inhibitory activity at $\beta$ thujaplicinol concentrations of up to $280 \mu \mathrm{M}$. Similar findings were made by Bristol-Myers researchers with aHT, which had MIC values of $90 \mu \mathrm{M}$ against Gram positive bacteria such as Staphylococcus aureus and Micrococcus lutues, while MIC values of $700 \mu \mathrm{M}$ and $360 \mu \mathrm{M}$ were observed for $P$. aeruginosa and Klebsiella pneumoniae, respectively. ${ }^{13}$ Escherichia coli strain NIHJ, however, showed sigfinicantly higher susceptibility, with an MIC of 45 $\mu \mathrm{M}$. It remains unclear why Gram-positive bacteria are more susceptible to the aHTs. In addition, like the fungicidal activity, tropolone demonstrated greater potency almost universally. This again suggests that the aHTs do not have any advantages over tropolones with respect to their antibacterial activity.

\section{Antitumor activity}

In 1988, researchers at Bristol-Myers reported their findings that 3,7-dihydroxytropolone, subsequently named BMY-28438, had potent cytotoxicity against cultured B16 melanoma cells. ${ }^{13}$ 3,7-Dihydroxytropolone displayed an $\mathrm{IC}_{50}$ value of $260 \mathrm{nM}$, which was over an order of magnitude more potent then either aHT or 4,7-dihydroxytropolone, and two orders of magnitude more potent than 5-hydroxytropolone (Figure 3). This trend suggests the importance of an array of contiguous oxygens, with more oxygens providing more potency. 3,7 Dihydroxytropolone was also shown to have non-specific inhibitory effects on DNA, RNA, and protein biosynthesis, with $\mathrm{IC}_{50}$ values of 60,90 , and $70 \mu \mathrm{M}$, respectively.

Animal model studies were also carried out with mice bearing tumors from the B16 cells. Excitingly, at concentrations of $1.3 \mathrm{mg} / \mathrm{kg} /$ day, the mice had a medium survival time of 29 days, which was almost double that of the untreated mice (16 days), and on par with $1 \mathrm{mg} / \mathrm{kg} /$ day of mitomycin C (27 days). This was in contrast to no effect with mice bearing tumors derived from a P388 leukemia cell line, which the molecules showed no activity in cellular assays. Unfortunately, slightly higher concentrations of the compound, $2.5 \mathrm{mg} / \mathrm{kg} /$ day, led to lower median survival rates (12 days), and $5 \mathrm{mg} / \mathrm{kg} /$ day was ruled toxic to the animals.

\section{Antimalarial activity}

An exciting recent discovery is the antimalarial activity of puberulic acid, reported by Otoguro, Shiomi, and coworkers at Kitasato University in 2011. ${ }^{14}$ In in vitro experiments against the chloroquine resistant Plasmodium falciparum K1 strain, the molecule showed an $\mathrm{IC}_{50}$ value of $50 \mathrm{nM}$, which was comparable to the value of artesunate in control experiments $(10 \mu \mathrm{M})$ (Figure 4$)$. The molecule also showed low background cytotoxicity, with an $\mathrm{IC}_{50}$ value against MRC-5 cell line of $360 \mu \mathrm{M}$. This selectivity was comparable with that of artesunate. The parent aHT did show significant activity, albeit not as potently as puberulic acid, but showed even higher cytotoxicity. Tropolone did not show any activity, suggesting the importance of added oxidation, although the activity of viticolin B was comparable to aHT, suggesting that the free hydroxyls are not necessary. The authors also carried out preliminary in vivo studies with an infected mouse model, and puberulic acid 
showed protective effects with an $\mathrm{ED}_{50}$ of $<2 \mathrm{mg} / \mathrm{kg} / \mathrm{day}$, which was again comparable to established antimalarial artesunate $(1.7 \mathrm{mg} / \mathrm{kg} /$ day $)$.

\section{Toxicological Studies}

Studies of the effects of $\beta$ thujaplicinol at higher concentrations in animal models have also been undertaken. ${ }^{12}$ At lower administrations of the compound $(50-100 \mathrm{mg} / \mathrm{kg})$, the mice demonstrated characteristics consistent with a depressant effect that lasted between 4-7 hours. During the period, mice maintained muscle control, and although they did not eat or drink, no deaths of the animals were reported. However, at higher concentrations of the compound (150-200 mg/kg), significantly different observations were made. The mice demonstrated characteristics consistent with stimulant effects, and some instances of convulsions occurred. Other effects noticed at higher concentrations were respiratory depression and lack of appetite. At these highest concentrations, all of the mice died within 48 hours. The lethal dose $\left(\mathrm{LD}_{50}\right)$ was found to be $175 \pm 4.2 \mathrm{mg} / \mathrm{kg}$ for a 48 hours monitoring period, and $155 \pm 4.5 \mathrm{mg} / \mathrm{kg}$ for a 72 hours monitoring period. This was in line with the dose found to lead to convulsions, which was $163 \mathrm{mg} / \mathrm{kg}$.

Follow-up studies of $\beta$-thujaplicinol along with other agents seemed to be more consistent with the depressent activity of the compounds. For example, mice that had been anesthetized using the barbiturates sodium thiopental and hexobarbital slept longer when $\beta$-thujaplicinol was also administered. Some differences were observed during these studies. Increases in sleeping periods were much more pronounced in the experiments run with sodium thiopental than those with hexobarbital. While both barbiturates prevented the convulsive effects of $\beta$ thujaplicinol, only hexobarbital prevented the lethal effects of the compound. Ethanolinduced sleep, meanwhile, was not prolonged by $\beta$ thujaplicinol. At low doses, $\beta$ thujaplicinol had synergistic activity on the depressant effects of chlorpromazine, as was observed based upon analysis of the drug's hypothermia and hyperkinesia effects. Similarly, the hypothermia effects of amphetamine, both the increase in body temperature followed by a drop in temperature, were delayed and amplified by $\beta$ thujaplicinol. However, the amphetamine-induced hyperkinesia activity on the mice was offset by $\beta$ thujaplicinol, with a sudden and dramatic decrease in activity observed upon administration of $\beta$-thujaplicinol.

These studies collectively demonstrate some potential side-effects of aHTs at higher concentrations, underscoring the importance of fine-tuning aHTs for a given target.

\section{Metalloenzyme inhibition}

The broad bioactivy displayed by aHTs suggests a possible mode of action, namely, an effect on dinuclear metalloenzymes, due to their ability to bind them in a manner that leverages the three contiguous oxygen atoms. The following sections summarize known metalloenzymes that are inhibited by aHTs.

\section{Inositol monophosphatase/alkaline phosphatase/dopamine $\beta$-oxygenase}

The first discussion on the potential privilege of aHTs for dinuclear metalloenzymes was laid out by Piettre and coworkers at Marion Merrell Research Institute in 1997. ${ }^{15}$ The researchers were drawn to recently patented work describing the potent inhibitory activity of 
puberulonic acid against inositol monophosphatase $\left(\mathrm{IC}_{50}=10 \mu \mathrm{M}\right)$, where a proposed binding mode suggested that hydrolysis of the anhydride would lead to a carboxylic acid that could serve as the metal-binding moiety. However, modeling studies based on crystallographic data suggested that the hydroxyls of the aHT were primarily responsible for binding to the metals, and did so in a way that leveraged the contiguous array of oxygens (Figure 5). To test this hypothesis, the researchers made a series of hydroxylated tropolones and found that a-hydroxytropolone was the minimal structure necessary for inhibiting inositol monophosphatase with an $\mathrm{IC}_{50}$ of $75 \mu \mathrm{M}$. Moreover, 3,7 dihydroxytropolone was found to have inhibitory activity comparable to puberulonic acid, demonstrating the anhydride was unnecessary and providing evidence against the initial proposed binding mode.

It was then hypothesized that this binding mode could be a general binding mode for dinuclear metalloenzymes. To test this hypothesis, tropolone, aHT, and 3,7dihydroxytropolone were tested against alkaline phosphatase and dopamine $\beta$ oxygenase (Figure 5). These each represented enzymes that used different divalent metal ions. Only ahydroxytropolone $\left(\mathrm{IC}_{50}=15 \mu \mathrm{M}\right)$ and 3,7 dihydroxytropolone $\left(\mathrm{IC}_{50}=60 \mu \mathrm{M}\right)$ were active against alkaline phosphatase. However, all three molecules were capable of potently inhibiting dopamine $\beta$ oxygenase $\left(\mathrm{IC}_{50}=2-3 \mu \mathrm{M}\right)$. The authors concluded that this binding mode might find utility against a broad range of enzymes, and suggested that those that recognize phosphoesters, similar to alkaline phosphatase and inositol monophosphatase, might be particularly strong candidates.

\section{HIV Reverse Transcriptase RNase H}

HIV Reverse Transcriptase (RT) RNase H has become a target for anti-HIV therapeutic development, ${ }^{16}$ and several inhibitors have been described. ${ }^{17}$ The aHT core has emerged from these studies as a promising pharmacophore that is arguably the most potent described to date.

In 2005, LeGrice, Beutler and coworkers published their findings that $\beta$-thujaplicinol was capable of potently inhibiting HIV-1 RT RNase $\mathrm{H}\left(\mathrm{IC}_{50}=0.21 \mu \mathrm{M}\right)$ (Figure 6) ${ }^{18}$ The importance of the aHT substructure was demonstrated by the fact that tropolone was inactive at a concentration of $100 \mu \mathrm{M}$. The molecule was also shown to be highly active against HIV-2 RT RNase $\mathrm{H}\left(\mathrm{IC}_{50}=0.77 \mu \mathrm{M}\right)$, and much less active against $E$. coli $\mathrm{RNase} \mathrm{H}$ $\left(\mathrm{IC}_{50}=50 \mu \mathrm{M}\right)$ and Human RNase $\mathrm{H}\left(\mathrm{IC}_{50}=5.7 \mu \mathrm{M}\right)$. The mechanism of binding has been determined by X-ray crystallography work by Arnold and coworkers, ${ }^{19}$ and is consistent with the mode proposed by Piettre and coworkers for IMPase. Unfortunately, $\beta$ thujaplicinol did not show any protective effects against the virus in cellular assays, likely at least in part due to competing cytotoxicity. As one of the most potent inhibitors of the enzyme known, $\beta$ thujaplicinol has since served an important role in understanding the role of HIV RT RNase $\mathrm{H}$ inhibitors, ${ }^{20}$ such as their ability to engage the enzyme simultaneously with polymerase inhibitors. $^{21}$ 


\section{Broad HIV Retroviral Activity of aHTs}

Coinciding with the work of Le Grice and Beutler, Marquet and coworkers carried out studies on 3,7-dihydroxytropolones that demonstrated that aHTs could have value in targeting multiple antiretroviral mechanisms simultaneously. ${ }^{5}$ Such a strategy could have profound benefits at overcoming the inherent issues of drug resistance. ${ }^{22} 3,7-$ dihydroxytropolone is not nearly as potent as $\beta$-thujaplicinol is against HIV RT RNase $\mathrm{H}$ $\left(\mathrm{IC}_{50}=20 \mu \mathrm{M}\right)$, but does have activity against HIV RT polymerase $\left(\mathrm{IC}_{50}=3.2 \mu \mathrm{M}\right)$, as well as HIV Integrase 3' processing $\left(\mathrm{IC}_{50}=40 \mu \mathrm{M}\right)$ and transfer $\left(\mathrm{IC}_{50}=11 \mu \mathrm{M}\right)$ activity (Figure 7). In addition, the compound is capable of inhibiting viral replication of HIV-1 in cellular assays with an $\mathrm{IC}_{50}$ value of $0.3 \mu \mathrm{M}$. Acylation of the tropolone led to inactivation against RNase $\mathrm{H}$ and IN 3' processing, demonstrating the importance of the free hydroxyls.

However, polymerase activity was still observed with only a minor decrease in potency. Subsequently, aHTs manicol and $\beta$ thujaplicinol were found to have similar activity against integrase, demonstrating that the minimal structure for activity is the aHT. ${ }^{23}$

\section{Hepatitis B and xenotropic murine leukemia virus related virus RNase $H$}

RNase $\mathrm{H}$ has been of interest for antiretroviral therapeutics of several other viruses, and aHTs have been identified as lead targets in this pursuit (Figure 8). Tavis, Hu and coworkers have recently shown that several molecules that are capable of inhibiting HIV RT RNase H are also capable of inhibiting hepatitis B viral (HBV) RNase H. ${ }^{24} \beta$ Thujaplicinol is one of these, as it inhibits HBV RNase $\mathrm{H}$ genotype D and $\mathrm{H}$ at $5.9 \mu \mathrm{M}$ and $2.3 \mu \mathrm{M}$, respectively. ${ }^{25}$ Despite being less potent than it is against HIV RT RNase $\mathrm{H}, \beta$ thujaplicinol was capable of inhibiting $\mathrm{HBV}$ replication $\left(\mathrm{EC}_{50}=5 \mu \mathrm{M}\right)$. To date, this is one of only two compounds known to inhibit HBV RT RNase H and inhibit hepadnaviral replication in cellular assays, the other being a napthiridone compound developed by researchers at Merck (Figure 8). ${ }^{17 \mathrm{~b}}$ Thus, aHTs could serve as a valuable starting point for the development of hepatitis B therapeutics.

The RNase $\mathrm{H}$ of xenotropic murine leukemia-virus related virus (XMRV) is also inhibited by $\beta$-thujaplicinol, a discovery made independently by Sarafianos ${ }^{26}$ and Wlodawer, ${ }^{27}$ along with their respective coworkers. In the Wlodawer studies, crystallographic data show that the molecule binds to the XMRV RNase H domain in a similar fashion to HIV RT RNase H. Furthermore, the molecule inhibited the XMRV RT RNase H in the same concentration range as HIV RT RNase H. Sarafianos and coworkers studied a series of HIV RT RNase H inhibitors against $\mathrm{XMRV}$, and likewise found that $\beta$ thujaplicinol was capable of inhibiting the enzyme $\left(\mathrm{IC}_{50}=1.4 \mu \mathrm{M}\right)$, although the Merck napthirydinone was more potent $\left(\mathrm{IC}_{50}=\right.$ $410 \mathrm{nM}$ ). In addition, $\beta$-thujaplicinol was not able to inhibit the RNase $\mathrm{H}$ at higher concentrations of substrate, as would be expected of a competitive inhibitor. The napthirydinone, on the other hand, maintained similar $\mathrm{IC}_{50}$ values at higher concentration of substrate, suggesting non-competitive binding or uncompetitive binding. It is important to realize that the napthyrindinone had previously undergone optimization by Merck, ${ }^{17 \mathrm{~b}}$ whereas $\beta$ thujaplicinol is an unoptimized natural product lead. Thus, it may be possible that aHTs could be developed that rival the napthyridinone. 


\section{Phosphotidylcholine-preferring Phospholipase C}

Phosphotidylcholine-preferring phospholipase $\mathrm{C}$ is a zinc metalloenzyme that cleaves phospholipids generating diacylglycerol and phosphorylated head groups. ${ }^{28}$ Recent studies have shown that PC-specific phospholipase $\mathrm{C}$ can downregulate HER2 overexpression on breast cancer cells, ${ }^{29}$ and thus inhibitors of the enzyme could be valuable for cancer treatment.

aHT has been shown to be a potent inhibitor of the enzyme $\left(\mathrm{K}_{\mathrm{i}}=16 \mu \mathrm{M}\right),{ }^{4,30}$ and is believed to bind through similar mechanism of other dinuclear metalloenzymes. Martin and coworkers made a series of hydroxyureas meant to mimic this binding ability. Several analogs were synthesized, but they were largely unable to inhibit the enzyme at a $\mathrm{pH}$ of 7.3, with one analog having a $\mathrm{K}_{\mathrm{i}}$ of $388 \mu \mathrm{M}$ (dihydroxylurea-1, Figure 9). At more basic $\mathrm{pH}$ (9.5), the inhibitors became more potent, likely due to the ability of the ureas to behave as dianions, as the analogs synthesized generally had higher $\mathrm{pK}_{\mathrm{a}}$ values. This suggests at the surface that the low $\mathrm{pK}_{\mathrm{a}}$ values of the aHTs play an important role in this bioactivity. However, that is not the complete picture, as another analog generated had comparable acidity to a hydroxytropolone and showed no activity at either $\mathrm{pH}$ (dihydroxylurea-2, Figure 9). In this case it may be possible that the geminal diethyl groups might lead to unfavorable steric interactions that prevents binding, highlighting the advantages of the aHT planarity.

\section{Aminoglycoside 2"-0-adenyltransferase [ANT(2")]}

A major pathway for resistance development by Gram-negative bacteria against aminoglycoside antibiotics is the enzymatic modification and deactivation of the antibiotics either via acetylation, phosphorylation, or adenylation. ${ }^{31}$ One of the most prevalent of these enzymes is aminoglycoside 2"-O-adenyltransferase [ANT(2")], which modifies the 2" alcohol of aminoglycosides such as gentamycin, tobramicin, and kanamycin and renders them inactive. ${ }^{32}$ While over 50 aminoglycoside-modifying enzymes exist, along with AAC(6'), ANT(2") is the most common determinant of enzyme-dependent aminoglycoside resistance to $P$. aeruginosa. ${ }^{33}$

In 1982, researchers at Eli Lilly reported that both aHT and $\beta$ thujaplicinol could inhibit ANT(2") (Figure 10). ${ }^{34}$ The $\mathrm{IC}_{50}$ value was not recorded, but at $100 \mu \mathrm{g} / \mathrm{mL}$ complete inhibition was observed, and close to $80 \%$ inhibition was seen for both compounds at 10 $\mu \mathrm{g} / \mathrm{mL}$. In addition, the compound was shown to work by competing with ATP for the enzyme. No inhibition at all was observed with tropolone, and significantly diminished activity was observed for 5 hydroxytropolone (59\% inhibition at $100 \mu \mathrm{g} / \mathrm{mL}$ ). aHT also showed modest potentiating effects against ANT(2")-positive, tobramicin-resistant bacteria both in cellular assays as well as in animal models. As the only inhibitor scaffold known for ANT(2"), aHTs could serve as valuable tools in studying this enzymatic function. They could also find use as potentiating co-drugs which would be used in combination with aminoglycoside antibiotics, similar to clavulanic acid with various $\beta$ lactam antibiotics. ${ }^{35}$

\section{Synthetic Chemistry-Driven Structure Function Studies}

While the promise of aHTs as therapeutic leads is apparent, a common problem with them is the cytotoxicity, likely due to their promiscuity. Thus, chemical modifications to these 
compounds are needed to improve the potency and selectivity before they can be evaluated as clinical candidates for various diseases. Surprisingly, very little has been published on synthetic chemistry-driven structure-function studies with an eye on enhancing selectivity and potency.

\section{Structure-function studies for inositol monophosphatase inhibitor development}

In an attempt to improve upon the activity of 3,7 dihydroxytropolones toward inositol monophosphatase (IMPase), Piettre and coworkers synthesized a series of monoaryl- and bisaryldihydroxytropolones. ${ }^{36}$ To access these molecules, 3,7 dihydroxytropolone was brominated to generate monobromo and bisbromodihydroxytropolones 1 and 2 in a 4.7:1 ratio at $57 \%$ conversion (Scheme 2). These were then protected with methyl groups using diazomethane, subjected to Suzuki cross-coupling reaction conditions with various arylboronic acids, and subsequently deprotected using TMSI/AcCN. Throughout their studies, the researchers synthesized 37 new dihydroxytropolones that were subsequently tested for their inhibitory activity against IMPase. The best molecule tested, 4 cyanophenyldihydroxytropolone (3), had an $\mathrm{IC}_{50}$ value of $4 \mu \mathrm{M}$, which was a slight increase in potency over the parent compound $\left(\mathrm{IC}_{50}=10 \mu \mathrm{M}\right)$.

\section{Structure-function studies for HIV RT and integrase inhibitor development}

A similar oxidation/cross-coupling approach was carried out by Marquet and coworkers in their development of broad activity HIV retroviral hydroxytropolones. ${ }^{5}$ Testing of over a dozen monoaryl and bisaryldihydroxytropolones did lead to some improved analogs against specific antiretroviral mechanisms. The most potent HIV RT polymerase inhibitor was the benzaldehyde-substituted monoaryldihydroxytropolone $4 \mathrm{a}\left(\mathrm{IC}_{50}=0.57 \mu \mathrm{M}\right.$ vs. $3.2 \mu \mathrm{M}$ of 3,7 dihydroxytropolone) (Figure 11). The most potent HIV RT RNase H inhibitor found was the 3 nitroaryl-substituted monoaryldihydroxytropolone $4 \mathrm{~b}$ ( $\mathrm{IC}_{50}=1.3 \mu \mathrm{M}$ vs. $20 \mu \mathrm{M}$ of 3,7 dihydroxytropolone).

Coincidentally, $4 \mathrm{~b}$ was also the most potent inhibitor of the integrase strand-transfer activity, and displayed over an order of magnitude potency increase over the parent compound $\left(\mathrm{IC}_{50}\right.$ $=0.78 \mu \mathrm{M}$ vs. $11 \mu \mathrm{M}$ of 3,7 dihydroxytropolone). The most dramatic increase in potency was for the integrase 3' processing potency, where a bisaryldihydroxytropolone with two Nacylphenyl groups $(4 \mathrm{c})$ showed over 2 orders of magnitude increase in potency over the parents 3,7-dihydroxytropolone ( $\mathrm{IC}_{50}=0.15 \mu \mathrm{M}$ vs. $40 \mu \mathrm{M}$ of 3,7 dihydroxytropolone). Many of the compounds tested showed protective effects in HIV replications assays using HIV-1 LAI/CEM-SS cells, although none of them reported were better than the parent compound. They also all proved to be inactive in an HIV-1 IIIB/MT-4 assay.

\section{Structure-function studies for HIV RT RNase H inhibitor development}

While $\beta$-thujaplicinol is arguably one of the most potent HIV RT RNase $\mathrm{H}$ inhibitors known to date, with an $\mathrm{IC}_{50}$ value of $200 \mathrm{nM}$, it is not active in viral replication assays. In an effort to improve the cellular efficacy of aHTs, LeGrice and coworkers carried out a series of studies on synthetic contructs that were modifications of the aHT natural product manicol. ${ }^{37}$ Like $\beta$-thujaplicinol, manicol has submicromolar activity against HIV RT RNase H, but does 
not work in cellular assays. In addition, manicol has an appended alkene which the researchers found could be modified.

To carry out the syntheses, manicol was acylated, and then a series of modifications to the alkene were carried out, such as ozonolysis, dihydroxylation and epoxidation reactions. These reactions led to new synthons that could be further functionalized. In total, the researchers synthesized 14 new manicol derivatives that were tested for their biological effects. While no derivatives displayed any significant increases in potency against HIV RT RNase $\mathrm{H}$ in enzymatic assays, they were all active $\left(\mathrm{IC}_{50}=<2 \mu \mathrm{M}\right)$. Many of the analogs are both significantly less cytotoxic and are capable of inhibiting viral replication in cellular assays. Surprisingly, the most potent analog synthesized, 5c, showed only weak activity in cellular antiviral assays (Figure 12).

\section{Summary of Synthetic chemistry-driven optimization studies of aHTs}

A common theme among the structure-function studies outlined above is that they all involve the semi-synthetic modification of aHTs. In the first two cases, this was through halogenation/cross-coupling methods, and in the latter case, it was through modification of manicol. While some exciting results have been obtained, these methods for structurefunction studies are limited by the diversity of chemical space that can be achieved. De novo synthetic approaches might be a more promising method for carrying out structure-function studies. The following section will outline proven strategies available to synthesize aHTs that could find value in future structure-function studies.

\section{Synthetic Access to a-Hydroxytropolones}

\section{Oxidation of tropones and tropolones}

The earliest synthetic work on aHTs focused on the oxidation of tropone or other troponoid compounds to aHT. This method, used commonly by Nozoe in his early work on the chemistry of tropolones, ${ }^{38}$ can be a rather efficient way to make the parent aHT. ${ }^{39}$ Most common methods for this involve halogenation of the tropone or tropolone followed by hydrolysis. This can be done directly or through intermediate acetolysis, such as the use of an acetic anhydride/ trifluoroacetic acid/ acetic acid mixture. ${ }^{40}$ One example demonstrating the oxidation strategy was in the total synthesis of puberulonic acid by Nozoe and coworkers from purpurogallin (Scheme 3). ${ }^{41}$ Unfortunately, as demonstrated by the aforementioned structure-function studies of Piettre and Marquet, this route does not lend itself to ready incorporation of diverse substitution patterns. ${ }^{5,36}$ Nevertheless, this approach has proved very valuable in the synthesis and study of polyhydroxylated tropones.

\section{Cyclopropanation/ring-opening routes}

Another strategy that has been used to access hydroxytropolones is the cyclopropanation of 6-membered rings followed by ring-openings. The first demonstration of this was in a synthesis puberulic acid by A. W. Johnson and coworkers in $1952 .{ }^{42}$ Their method to this molecule leveraged a cyclopropanation of 1,2,4-trimethoxybenzene with ethyldiazoacetate followed by a $6 \pi$ electrocyclic ring-opening to generate the 7-membered ring (Scheme 4). Subsequent hydrolysis and oxidation of the compound led to the natural product. 
In a more recent study by Balci and coworkers, a similarly generated cycloheptatriene was shown to serve as a precursor to aHTs (Scheme 5). ${ }^{43}$ In this elegant work, cyclohexatrienes generated through cyclopropanation/ $6 \pi$ electrocyclic ring-opening on 1,3-benzodioxole were oxidized with singlet oxygen to generate endoperoxides. Subsequent treatment with cobalt tetraphenylporphorine promoted the rearrangment to aHTs. Based on previous work by Balci and Foote, it is assumed that this transformation proceeds through a bis-epoxide intermediate. $^{44}$

Banwell and coworkers have used cyclopropanation of various cycloalkenes followed by a ring-opening to generate aHTs. ${ }^{45}$ Unlike the previously described works, the cyclopropane products generated are not set up for an immediate electrocyclic ring-opening. Instead, Grob fragmentation strategies were developed to accomplish the ring-openings; however, the possibility that these conditions may promote enolization to the divinyl cyclopropanes, which could then undergo the electrocyclic ring-opening, cannot be ruled out. Of particular relevance to structure-function studies are cyclopropanation methods that use bromoform and base to generate dibromocyclopropanes that can be converted to bromotropolones. These bromotropolones can be modified through cross-coupling and then demethylated to generate the aHTs, ${ }^{46}$ and thus could serve as a valuable, modifiable late-stage synthetic intermediate. This strategy was also modified to generate 3,7 dihydroxytropolones. This versatility is highlighted in the synthesis of both $\beta$ thujaplicinol (Scheme 6$)^{47}$ and puberulic acid (Scheme 7). ${ }^{48}$

\section{Ring-openings of 8-oxabicyclo[3.2.1]octenes}

8-Oxabicyclo[3.2.1] octenes have been used widely as intermediates in the synthesis of various troponoid compounds, ${ }^{49}$ and thus strategies for adapting this strategy to aHT synthesis have also emerged.

The first of these methods was carried out by Föhlisch and coworkers (Scheme 8). In this work, 8 oxabicyclo[3.2.1] octenes were generated through a cycloaddition reaction between pentachloroacetone and substituted furan. ${ }^{50}$ The resultant compound was then able to undergo a base-mediated ring-opening to provide the a methoxytropolone, which could be subsequently converted to the hydroxytropolone by $\mathrm{HBr} / \mathrm{AcOH}$ demethylation. The group showed this method starting with furan starting materials substituted at both the 2- and 3positions could afford monoalkyl substituted aHTs, including $\beta$ thujaplicinol, with different substitution patterns.

Our lab has demonstrated an alternative method using 8 oxabicyclo[3.2.1]octene intermediates that allows for di and trisubstituted aHTs (Scheme 9). In this method, an a hydroxy $\gamma$ pyrone-based oxidopyrylium cycloaddition affords the 8-oxabicyclo[3.2.1]octene intermediates, which can undergo acid-mediated ring-openings. While triflic-acid mediated ring-openings of the molecules lead to a methoxytropolones, ${ }^{51}$ in the presence of $\mathrm{BCl}_{3}$, some of these bicyclic compounds can go directly to the aHTs. ${ }^{52}$ Among the advantages to our approach are the use of readily available alkynes, and the ability to bring in diverse substitution patterns. 


\section{Cyclopropanation/Cope rearrangment}

While not applied directly to aHTs, Davies and coworkers have shown that a cyclopropanation/Cope rearrangement strategy can be employed toward dimethoxytropones that are only a demethylation reaction away from aHTs (Scheme 10). ${ }^{53}$ In this approach, a series of vinyldiazomethane compounds were subjected to rhodium-mediated cyclopropanation of highly oxidized dienes to afford cycloheptadienes. Upon subjecting them to DDQ oxidation, 2,7-dimethoxytropones were formed.

\section{Conclusion}

aHTs have a broad range of bioactivity, and thus have the potential to serve as a common pharmacophore through which new therapeutics can be developed. However, to date this potential has not been fully gauged in large part due to a scarcity of synthetic chemistrydriven structure-function studies. Thus, there are rich opportunities for researchers to identify new enzymatic targets of aHTs, use the current methods in new and more thorough structure-function studies, and develop new synthetic methods and strategies that could be used in pursuit of therapeutically viable aHTs analogs.

\section{Acknowledgments}

The authors are grateful for financial support from Brooklyn College and the National Institutes of Health (SC2GM099596). We also thank Dr. John Beutler (NCI at Frederick) and Dr. John Tavis (Saint Louis University School of Medicine) for helpful discussions and feedback in the preparation of this review article.

\section{Notes and references}

1. Isin DO, Karakus N. J. Mol. Model. 2010; 16:1877-1882. [PubMed: 20232098]

2. For a recent review on tropolones, see: Bentley R. Nat. Prod. Rep. 2008; 25:118-138. [PubMed: 18250899]

3. Pauson PL. Chem. Rev. 1955; 55:9.

4. Martin SF, Follows BC, Hergenrother PJ, Franklin CLJ. Org. Chem. 2000; 65:4509-4514.

5. Didierjean J, Isel C, Querré F, Mouscadet JF, Aubertin AM, Valnot JV, Piettre SR, Marquet R. Antimicrob. Agents Chemother. 2005; 49:4884-4894. [PubMed: 16304149]

6. Mó O, Yáñez M, Esseffar M, Herreros M, Notario R, Abboud JL-M. J. Org. Chem. 1997; 62:32003207. [PubMed: 11671704]

7. Gardner JAF, Barton GM, Maclean H. Can. J. Chem. 1957; 35:1039-1048.

8. Sowden AM. Ind. Eng. Chem. 1929; 21:981-984.

9. For examples, see: Morris PI, Stirling R. Wood Sci. Technol. 2012; 46:991-1002. Chedgy RJ, Lim YW, Brueil C. Can. J. Microbiol. 2009; 55:578-586. [PubMed: 19483786]

10. Roff JW, Whittaker EI. Can. J. Bot. 1959; 37:1132-1134.

11. Kousha M, Tadi R, Soubani AO. Eur. Respir. Rev. 2011; 121:156-174. [PubMed: 21881144]

12. Sanders, HD. M.S. Thesis. Canada: The University of British Columbia; 1961. Some pharmacological and microbiological studies on beta-hydroxy thujaplicin. (available online through the University of British Columbia library at https://circle.ubc.ca/handle/2429/39828)

13. Sugawara K, Ohbayashi M, Shimizu K, Hatori M, Kamei H, Konishi M, Oki T, Kawaguchi H. J. Antibiot. 2011; 64:862-868.

14. Iwatsuki M, Takada S, Mori M, Ishiyama A, Namatame M, Otoguro K, Nishihara-Tsukashima A, Nonaka K, Masuma R, Otoguro O, Shiomi K, Omura S. J. Antibiot. 2011; 64:183-188. [PubMed: 21063422] 
15. Piettre SR, Ganzhorn A, Hoflack J, Islam K, Hornsperger JM. J. Am. Chem. Soc. 1997; 119:32013204.

16. Ilina T, LaBarge K, Sarafianos SG, Ishima R, Parniak MA. Biology. 2012; 1:521-541. [PubMed: 23599900]

17. For some examples, see: Su HP, Yan Y, Prasad S, Smith RF, Daniels CL, Abeywickrema PD, Reid JC, Loughran HM, Kornienko M, Sharma S, Grobler JA, Xu B, Sardana V, Allison TJ, Williams PD, Darke PL, Hazuda DJ, Munshi S S. J. Virol. 2010; 84:7625-7633. [PubMed: 20484498] Williams PD, Staas DD, Venkatraman S, Loughran HM, Ruzek RD, Booth TM, Lyle TA, Wai JS, Vacca JP, Feuston BP, Ecto LT, Flynn JA, DiStefano DJ, Hazuda DJ, Bahnck CM, Himmelberger AL, Dornadula G, Hrin RC, Stillmock KA, Witmer MV, Miller MD, Grobler JA. Biooganic. Med. Chem. Lett. 2010; 20:6754-6757. Kirschberg TA, Balakrishnan M, Squires NH, Barnes T, Brendza KM, Chen X, Eisenberg EJ, Jin W, Kutty N, Leavitt S, Liclican A, Liu Q, Liu X, Mak J, Perry JK, Wang M, Watkins WJ, Lansdon EB. J. Med. Chem. Lett. 2009; 52:5781-5784. Wendeler M, Lee MH-F, Bermingham A, Miller JT, Chertov O, Bona MK, Baichoo NS, Ehtesham M, Beutler JA, O'Keefe BR, Gotte M, Kvaratskhelia M, Le Grice SFJ. ACS Chem. Biol. 2008; 3:635-644. [PubMed: 18831589] Chung S, Wendeler M, Rausch JW, Beilhartz G, Gotte M, O'Keefe BR, Bermingham A, Beutler JA, Liu S, Zhuang X, Le Grice SFJ. Antimicrob. Agents Chemother. 2010; 54:3913-3921. [PubMed: 20547794]

18. Budihas SR, Gorshkova I, Gaidamakov S, Wamiru A, Bona MK, Parniak MMA, Crouch RJ, McMahon JB, Beutler JA, A J, Le Grice SFJ. Nuc. Acids Res. 2005; 33:1249-1256.

19. Sarafianos SG, Marchand B, Das K, Himmel DH, Parniak MA, Hughes SH, Arnold E. J. Mol. Biol. 2009; 385:693-713. [PubMed: 19022262]

20. For examples, see: Herman BD, Sluis-Cremer N. Biochem. J. 2013; 455:179-184. [PubMed: 23927736] Himmel DM, Maegley KA, Pauly TA, Bauman JD, Das K, Dharia C, Clark AD, Ryan K, Hickey MJ, Love RA, Hughes SH, Bergqvist S, Arnold E. Structure. 2009:1625-1635. [PubMed: 20004166] Poongavanam V, Kongsted J. PLoS One. 2013; 8:e73478. [PubMed: 24066050]

21. Beilhartz GL, Wendeler M, Baichoo N, Rausch J, Le Grice S, Gotte M. J. Mol. Biol. 2009; 388:462-474. [PubMed: 19289131]

22. For a recent review on the challenges of resistance in HIV treatment, see: Cossarini F, Spagnuolo V, Gianotti N, Carbone A, Lazzarin A, Castagna A. New Microbiol. 2013; 36:23-39. [PubMed: 23435813]

23. Semenova EA, Johnson AA, Marchand C, Davis DA, Yarchoan R, Pommier Y. Mol. Pharmacol. 2006; 69:1454-1460. [PubMed: 16418335]

24. Tavis JE, Cheng X, Hu Y, Totten M, Cao F, Michailidis E, Aurora R, Meyers MJ, Jacobnsen J, Parniak M, Sarafianos SG. PLoS Pathogens. 2013; 9:e1003125. [PubMed: 23349632]

25. Hu Y, Cheng X, Cao F, Tavis JE. Antiviral Res. 2013; 99:221-229. [PubMed: 23796982]

26. Kirby KA, Marchand B, Ong YT, Ndongwe TP, Hachiya A, Michailidis E, Leslie MD, Sietsema DV, Fetterly TL, Dorst CA, Singh K, Wang Z, Parniak MA, Sarafianos SG. Antimicrob. Agents Chemother. 2012; 56:2048-2061. [PubMed: 22252812]

27. Zhou D, Chung S, Miller M, Le Grice SFJ, Wlodawar A. J. Struct. Biol. 2012; 117:638-645. [PubMed: 22366278]

28. Exton JH. Eur. J. Biochem. 1997; 243:10-20. [PubMed: 9030716]

29. Paris L, Cecchetti S, Spadaro F, Abalsamo L, Lugini L, Pasanu ME, Iorio E, Natali PG, Ramoni C, Podo F. Breast Cancer Res. 2010; 12:R27. [PubMed: 20462431]

30. Li, H. A. PhD Thesis. United States of America: The University of Texas at Austin; 2005. Synthesis and kinetic evaluation of substrate-based phospholipid analogues and studies towards the synthesis of 5-hydroxyaloin A. (available online through the University of Texas Digital Despository at http://repositories.lib.utexas.edu/handle/2152/1612)

31. For some lead reviews, see: Mingeot-Leclercq M-P, Glupczynski Y, Tulkens PM. Antimicrob. Agents Chemother. 1999; 43:727-737. [PubMed: 10103173] Davies J, Wright GD. Trends in Microbiology. 1997; 5:234-240. [PubMed: 9211644] Wright GD. Chemistry and Biology. 2000; 7:R127-R132. [PubMed: 10873842] 
32. For lead references, see: Bongaerts GP, Molendjik L. Antimicrob. Agents Chemother. 1984; 25:234-237. [PubMed: 6324668] Wright E, Serpersu EH. Biochemistry. 2005; 44:11581-11591. [PubMed: 16114895]

33. Poole K. Antimicrob. Agents Chemother. 2005; 49:479-487. [PubMed: 15673721]

34. (a) Allen NE, Alborn WE Jr, Hobbs JN Jr, Kirst HA. Antimicrob. Agents Chemother. 1982; 22:824-831. [PubMed: 6185088] (b) Kirst HA, Marconi GG, Counter FT, Ensminger PW, Jones ND, Chaney MO, Toth JE, Allen NE. Antibiot. 1982; 35:1651-1657.

35. For a review, see: Saudagar PS, Survase SA, Singhai RS. Biotechnol. Adv. 2008; 26:335-351. [PubMed: 18450406]

36. Piettre SR, André C, Chanal MC, Ducep JB, Lesur B, Piriou F, Raboisson P, Rondeau JM, Schelcher C, Zimmermann P, Ganzhorn AJ. J. Med. Chem. 1997; 40:4208-4221. [PubMed: 9435892]

37. Chung S, Himmel DM, Jiang JK, Wojtak K, Bauman JD, Rausch JW, Wilson JA, Beutler JA, Thomas CJ, Arnold E, Le Grice SFJ. J. Med. Chem. 2011; 54:4462-4473. [PubMed: 21568335]

38. Nozoe T, Seto S, Itô S, Sato M, Katono T. Sci. Rep. Tohoku Univ. Ser. 1. 1953; 37:191-210.

39. (a) Ito S, Hirama M. Tethrahedron Lett. 1975; 16:1071-1074.(b) Davey W, Gottfried H. J. Org. Chem. 1961; 26:3699-3702.(c) Takeshita H, Mori A. Synthesis. 1986:578-579.

40. Takeshita H, Mori A, Kusaba T, Watanabe H. Bull. Chem. Soc. Jpn. 1987; 60:4325-4333.

41. Nozoe T, Doi K, Hashimoto T. Bull. Chem. Soc. Jpn. 1960; 33:1071-1074.

42. (a) Corbett RE, Hassall CH, Johnson AW, Todd AR. J. Chem. Soc. 1950:1-6.(b) Corbett RE, Johnson AW, Todd AR. J. Chem. Soc. 1950:6-9.(c) Johns RB, Johnson AW, Murray J. J. Chem. Soc. 1954:198-202.

43. Dastan A, Saracuglu N, Balci M. Eur. J. Org. Chem. 2001:3519-3522.

44. (a) Boyd JD, Foote CS, Imagawa DK. J. Am. Chem. Soc. 1980; 102:3641-3642.(b) Sütbeyaz Y, Secen H, Balci M. J. Org. Chem. 1988; 53:2312-2317.(c) Balci M, Akbulut N. Tetrahedron. 1985; 41:1315-1322.

45. Banwell MG, Collis MP. J. Chem. Soc., Perkin Trans. 1. 1992:1329-1334.

46. (a) Banwell MG. Pure Appl. Chem. 1996; 68:539-542.(b) Banwell MG, Cameron JM, Collis MP, Crisp GT, Gable RW, Hamel E, Lambert JN, Mackay MF, Reum ME, Scoble JA. Aust. J. Chem. 1991; 44:705-728.

47. Banwell MG, Collis MP, Crisp GT, Lambert JN, Reum ME, Scoble JA. J. Chem. Soc., Chem. Commun. 1989; 10:616-617.

48. Banwell MG, Collis MP, Mackay MF, Richards SL. J. Chem. Soc., Perkin Trans. 1. 1993:19131920.

49. For examples, see: Baldwin JE, Mayweg AVW, Neuman K, Prichard GJ. Org. Lett. 1999; 1:19331935. [PubMed: 10905860] Adlington RM, Baldwin JE, Mayweg AVW, Pritchard GJ. Org. Lett. 2002; 4:3009-3011. [PubMed: 12182611] Baldwin, J. JE, Mayweg AVW, Pritchard GJ, Adlington RM. Tetrahedron Lett. 2003; 44:4543-4545. Graening T, Bette V, Neudorfl J, Lex J, Schmalz HG. Org. Lett. 2005; 7:4317-4320. [PubMed: 16178522]

50. Zinser J, Henkel S, Föhlisch B. Eur. J. Org. Chem. 2004:1344-1356.

51. Williams YD, Meck C, Mohd N, Murelli RP. J. Org. Chem. 2013; 78:11707-11712. [PubMed: 24171600]

52. Meck C, Mohd N, Murelli RP. Org. Lett. 2012; 14:5988-5991. [PubMed: 23167954]

53. Davies HML, Clark TJ. Tetrahedron. 1994; 50:9883-9892. 
<smiles>O=c1c(O)ccccc1O</smiles><smiles>O=c1c(O)ccc([Te])cc1O</smiles><smiles>C=C(C)[C@H]1CCc2c(c(C)cc(O)c(=O)c2O)C1</smiles>
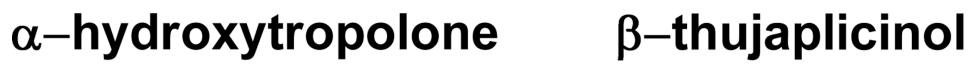

manicol<smiles>O=C(O)c1cc(O)c(O)c(=O)c(O)c1</smiles><smiles>O=C1OC(=O)c2c1cc(O)c(=O)c(O)c2O</smiles>

puberulic acid puberulonic acid<smiles></smiles>
Xenovulene A metabolite

Figure 1.

a-Hydroxytropolone and related natural products. 


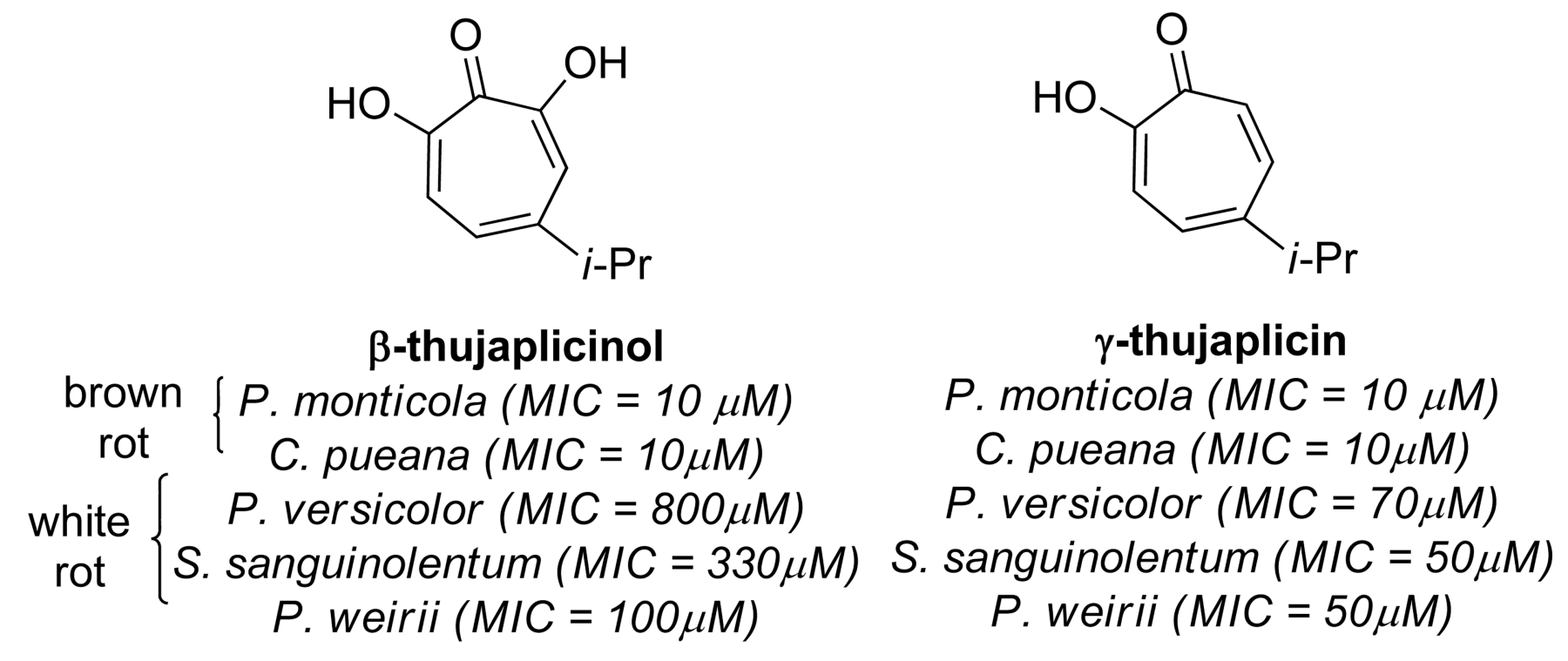

Figure 2.

Examples of thujaplicin natural product antifungal activity 
<smiles>O=c1c(O)cccc(O)c1O</smiles><smiles>O=c1c(O)ccccc1O</smiles>

3,7-dihydroxytropolone (BMY-28438) $\mathrm{IC}_{50}=250 \mathrm{nM}$

\section{$\alpha$-Hydroxytropolone $\mathrm{IC}_{50}=2.2 \mu \mathrm{M}$}<smiles>O=c1c(O)ccc(O)cc1O</smiles>

4,7-dihydroxytropolone $\mathrm{IC}_{50}=2.5 \mu \mathrm{M}$

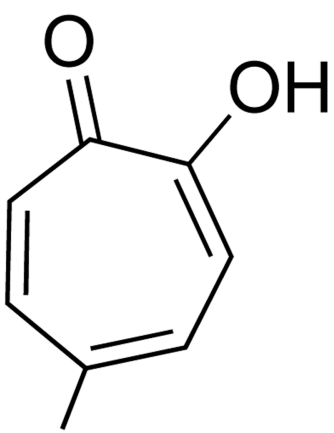

$\mathrm{HO}$

5-hydroxytropolone $\mathrm{IC}_{50}=13 \mu \mathrm{M}$

Figure 3.

Cytotoxic activity of tropolones against B16 melanoma 
<smiles>O=C(O)c1cc(O)c(O)c(=O)c(O)c1</smiles>

puberulic acid

$K 1$ strain $I C_{50}=50 n M$

FCR3 strain $I C_{50}=50 \mathrm{nM}$

MRC-5 IC ${ }_{50}=360 \mu \mathrm{M}$

mouse model $E D_{50}=<2 \mathrm{mg} / \mathrm{kg}$<smiles>O=c1c(O)ccccc1O</smiles>

$\alpha$-hydroxytropolone

$K 1$ strain $I C_{50}=6.4 \mu \mathrm{M}$

FCR3 strain IC $I_{50}=8.7 \mu \mathrm{M}$

MRC-5 IC $50=1.7 \mu \mathrm{M}$

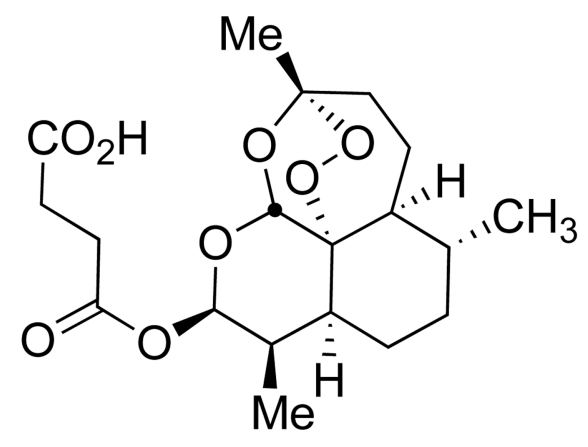

artesunate

$K 1$ strain $I C_{50}=10 \mathrm{nM}$

FCR3 strain $I C_{50}=2.5 \mathrm{nM}$

MRC-5 IC $50=36 \mu \mathrm{M}$

mouse model $E D_{50}=1.7 \mathrm{mg} / \mathrm{kg}$<smiles>O=c1cccccc1O</smiles>

tropolone

$K 1$ strain $I C_{50}=>100 \mu \mathrm{M}$<smiles>COc1cc(C(=O)O)cc(O)c(OC)c1=O</smiles>

viticolin B

$K 1$ strain $I C_{50}=3.7 \mu \mathrm{M}$

Figure 4.

Representative examples from studies of puberulic acid against $P$. falcifarum chloroquineresistant K1 strain, and sensitive FCR3 strain. 


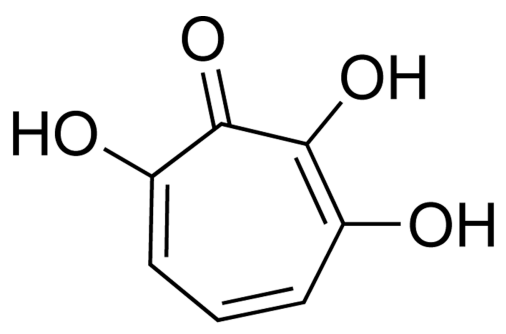

3,7-dihydroxytropolone IMPase $(\mathrm{Mg}-\mathrm{Mg}) / \mathrm{C}_{50}=8 \mu \mathrm{M}$ APase $(Z n-Z n) I C_{50}=60 \mu M$ $\operatorname{DBM}(\mathrm{Cu}-\mathrm{Cu}) I_{50}=3 \mu \mathrm{M}$

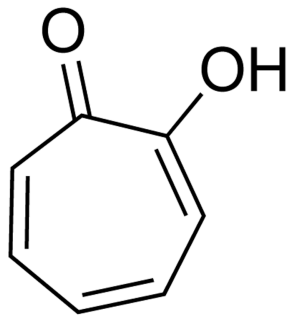

\section{tropolone}

$$
\begin{gathered}
\text { IMPase }(M g-M g) / C_{50}=>1 \mathrm{mM} \\
\text { APase }(Z n-Z n) / C_{50}=>1 \mathrm{mM} \\
\text { DBM }(\mathrm{Cu}-\mathrm{Cu}) / C_{50}=2 \mu \mathrm{M}
\end{gathered}
$$

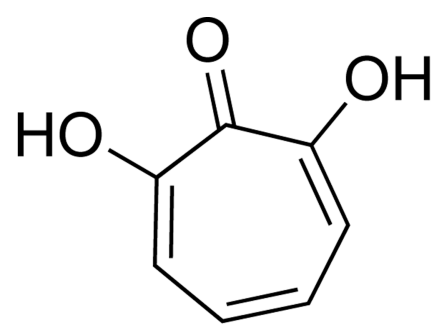

$\alpha$-hydroxytropolone

IMPase $(M g-M g) / C_{50}=75 \mu M$

APase $(Z n-Z n) I C_{50}=15 \mu M$

$\operatorname{DBM}(\mathrm{Cu}-\mathrm{Cu}) I_{50}=2 \mu \mathrm{M}$

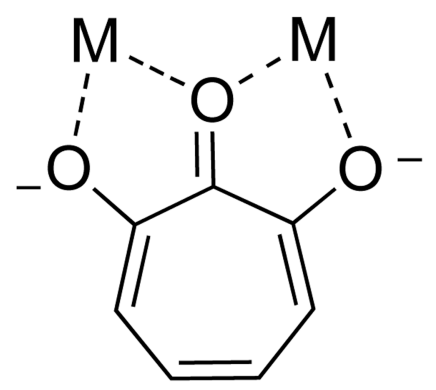

proposed binding mode for IMPase

Figure 5 .

Examples of tropolone activity against dinuclear metalloenzymes inositol monophosphatase (IMPase), alkaline phosphatase (APase), and dopamine $\beta$-oxygenase (DBM), as well as the hypothesized binding mode. 
<smiles>O=c1c(O)ccc([Te])cc1O</smiles>

\section{$\beta$-thujaplicinol}

HIV-1 RT RNase HIC $I_{50}=0.2 \mu \mathrm{M}$ HIV-2 RT RNase HIC $I_{50}=0.8 \mu \mathrm{M}$

E. coli RNase $H I C_{50}=50 \mu M$ Human RNase $H_{I} C_{50}=5.7 \mu M$
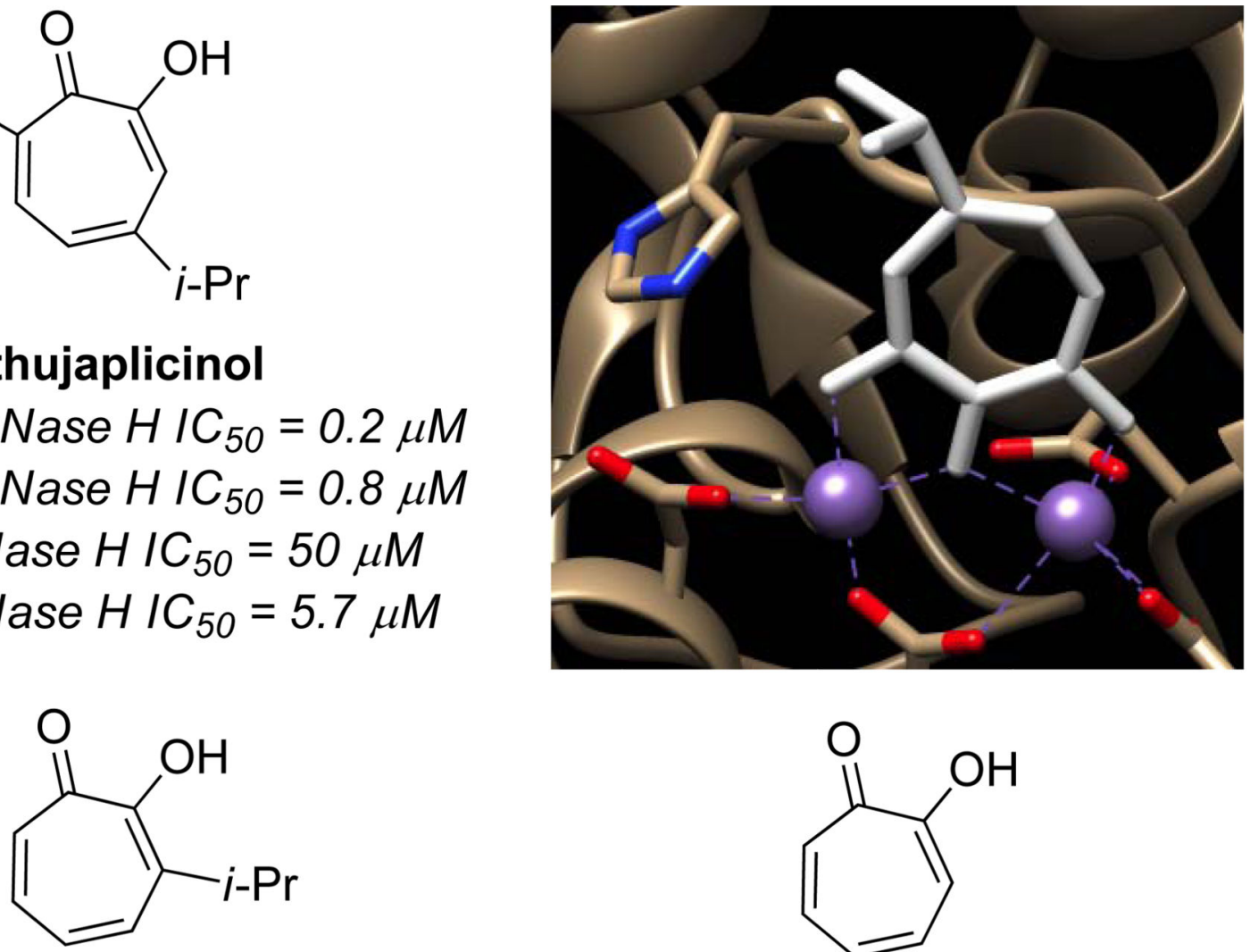

$\alpha$-thujaplicin

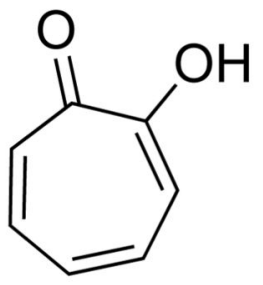

\section{tropolone}

HIV-1 RT RNase HIC $\mathrm{C}_{50}=50 \mu \mathrm{M}$ HIV-1 RT RNase H IC $50=>100 \mu M$ HIV-2 RT RNase H IC $50=33 \mu \mathrm{M}$ HIV-2 RT RNase H IC $50=>100 \mu \mathrm{M}$

E. coli RNase $H / C_{50}=>1000 \mu M$ E. coli RNase $H / C_{50}=>100 \mu M$ Human RNase $\mathrm{H} / \mathrm{C}_{50}=12 \mu \mathrm{M}$ Human RNase $\mathrm{H} I C_{50}=3.0 \mu M$

Figure 6.

Examples of tropolone activity against RNase $\mathrm{H}$ enzymes, as well as a crystal structure showing $\beta$-thujaplicinol bound to the active site (derived from pdb $3 \mathrm{~K} 2 \mathrm{P}$ ). 
<smiles>O=c1c(O)cccc(O)c1O</smiles>

3,7-dihydroxytropolone $R T$ RNase $H I C_{50}=20 \mu \mathrm{M}$ $R T$ polymerase $I C_{50}=3.2 \mu \mathrm{M}$ IN 3' processing $I C_{50}=40 \mu \mathrm{M}$ IN transfer $I C_{50}=11 \mu \mathrm{M}$<smiles>COc1cccc(OC)c(=O)c1OC</smiles>

acylated 3,7-dihydroxytropolone $R T$ RNase $H I C_{50}=>1 \mathrm{mM}$ $R T$ polymerase $I C_{50}=30 \mu \mathrm{M}$ $I N$ 3' processing $I C_{50}=>1 \mathrm{mM}$ $I N$ transfer $I C_{50}=$ not determined

Figure 7.

Activity of 3,7-dihydroxytropolone and an acylated derivative against several HIV antiretroviral targets. 


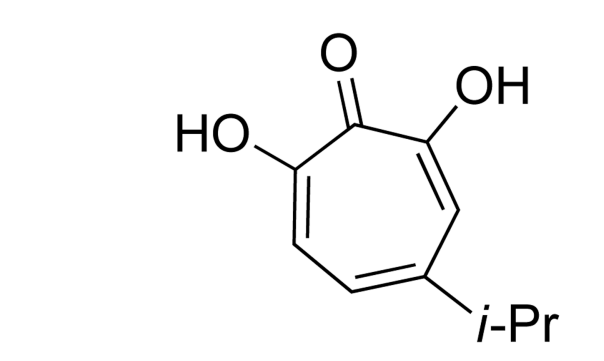

$\beta$-thujaplicinol

$H B V$ RNase $H I C_{50}=5.9 \mu \mathrm{M}$

$H B V$ antiviral $E C_{50}=5 \mu \mathrm{M}$

$X M R V$ RNase $H I C_{50}=1.4 \mu M$

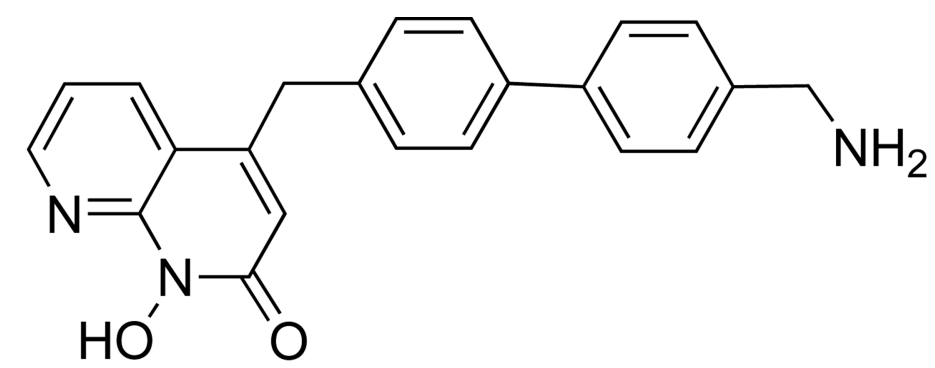

Merck napthyridinone HBV RNase $\mathrm{H} I C_{50}=2.5 \mu \mathrm{M}$

$H B V$ antiviral $=93 \%$ inhibition at $10 \mu \mathrm{M}$ $X M R V$ RNase $H / C_{50}=410 \mathrm{nM}$

Figure 8.

Representative results of $\beta$-thujaplicinol and Merck napthyridinone activity against HBV and XMRV RNase H. HBV RNase $\mathrm{H} \mathrm{IC}_{50}$ value is with genotype D for comparative purposes. 
<smiles>O=c1c(O)ccccc1O</smiles>

$\alpha$-hydroxytropolone $p K_{a 1}, p K_{a 2}=5.6,7.0$ $p H 7.3, K_{i}=16 \mu M$ $p H$ 9.5, $K_{i}=23 \mu M$<smiles>O=C1C=CCN(O)C(=O)N1O</smiles>

\section{dihydroxylurea-1}

$p K_{a 1}, p K_{a 2}=5.0,8.7$

$p H 7.3, K_{i}=388 \mu M$

$p H$ 9.5, $K_{i}=53 \mu M$<smiles>CCC1(CC)C(=O)N(O)C(=O)N(O)C1=O</smiles>
dihydroxylurea-2 $p K_{a 1}, p K_{a 2}=5.6,7.1$ pH 7.3, no inhibition pH 9.5, no inhibition

Figure 9.

Activity of a-hydroxytropolone against PC-specific phospholipase $\mathrm{C}$ at $\mathrm{pH} 7.3$ and 9.5, along with compounds designed to mimic this inhibitory activity. 
<smiles>O=c1c(O)ccccc1O</smiles>

$\alpha$-hydroxytropolone $550 \mu \mathrm{M}, 100 \%$ inhibition $55 \mu \mathrm{M}, 78 \%$ inhibition $5.5 \mu \mathrm{M}, 8 \%$ inhibition<smiles>O=c1c(O)ccc([Te])cc1O</smiles>

$\beta$-thujaplicinol $730 \mu \mathrm{M}, 100 \%$ inhibition $73 \mu \mathrm{M}, 76 \%$ inhibition $7.3 \mu \mathrm{M}, 31 \%$ inhibition<smiles>O=c1c(O)cccc(O)c1O</smiles>

3,7-dihydroxytropolone $650 \mu \mathrm{M}, 54 \%$ inhibition $65 \mu \mathrm{M}$, no inhibition $6.5 \mu \mathrm{M}, 2 \%$ inhibition

Figure 10.

Inhibitory activity of select aHTs against ANT(2") at various concentrations 

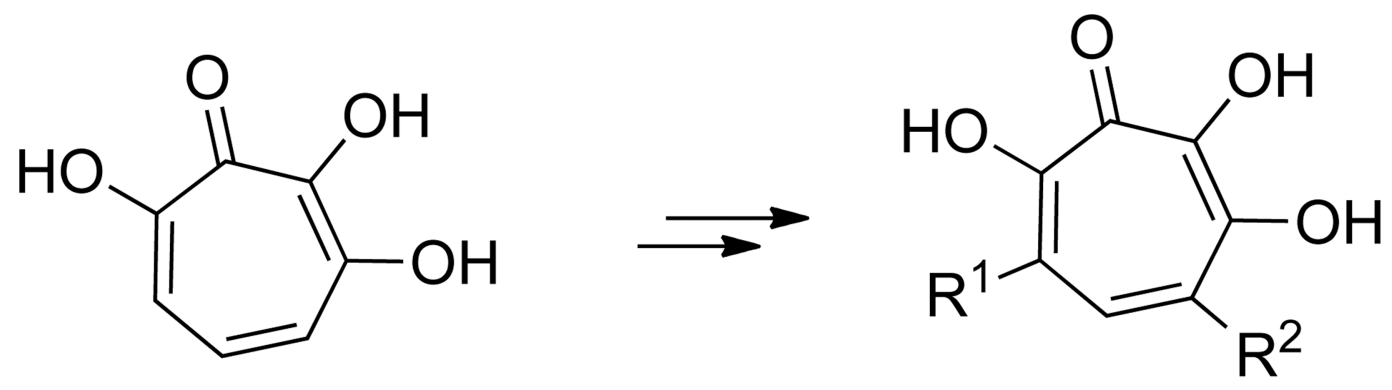

4a-c

3,7-dihydroxytropolone

RT RNase $\mathrm{H} I \mathrm{C}_{50}=20 \mu \mathrm{M}$

$R T$ polymerase $I C_{50}=3.2 \mu \mathrm{M}$

IN 3' processing $I C_{50}=40 \mu \mathrm{M}$

IN transfer $I C_{50}=11 \mu \mathrm{M}$ 4a, $\mathrm{R}^{1}=\mathrm{H}, \mathrm{R}^{2}=4-\mathrm{CHOC}_{6} \mathrm{H}_{4}$ RT RNase H IC So $_{50}=12 \mu \mathrm{M}$ $R T$ polymerase $I C_{50}=0.6 \mu \mathrm{M}$ IN 3' processing $I C_{50}=0.6 \mu \mathrm{M}$ $I N$ transfer $I C_{50}=1.2 \mu \mathrm{M}$
4b, $\mathrm{R}^{1}=\mathrm{H}, \mathrm{R}^{2}=3-\mathrm{NO}_{2} \mathrm{C}_{6} \mathrm{H}_{4}$
4c, $\mathrm{R}^{1}=\mathrm{R}^{2}=4-\mathrm{AcNC}_{6} \mathrm{H}_{4}$

RT RNase H IC $\mathrm{C}_{50}=1.3 \mu \mathrm{M}$

$R T$ RNase $H I C_{50}=0.9 \mathrm{mM}$

$R T$ polymerase $I C_{50}=2.3 \mu \mathrm{M} \quad R T$ polymerase $I C_{50}=52 \mu \mathrm{M}$

$I N 3^{\prime}$ processing $I C_{50}=0.7 \mu \mathrm{M} I N 3^{\prime}$ processing $I C_{50}=0.15 \mu \mathrm{M}$

IN transfer $I C_{50}=0.8 \mu \mathrm{M}$

IN transfer $I C_{50}=1.7 \mu \mathrm{M}$

Figure 11.

Examples of synthetic modifications of 3,7-dihydroxytropolone and examples of their inhibitory potency against various HIV antiviral targets. 
<smiles>C=C(C)[C@H]1CCc2c(c(C)cc(O)c(=O)c2O)C1</smiles>

manicol

HIV RT RNase $\mathrm{H} \mathrm{IC}_{50}=600 \mathrm{nM}$

No antiviral activity

T Cell Cytotoxicity $\mathrm{CC}_{50}=13.5 \mu \mathrm{M}$<smiles>Cc1cc(O)c(=O)c(O)c2c1C[C@H](C(C)(O)CBr)CC2</smiles>

manicol derivative $5 \mathrm{~b}$

HIV RT RNase $\mathrm{H} \mathrm{IC}_{50}=13 \mu \mathrm{M}$

Cellular Antiviral Activity $\mathrm{EC}_{50}=4.2 \mu \mathrm{M}$

T Cell Cytotoxicity $\mathrm{CC}_{50}=17.4 \mu \mathrm{M}$<smiles>Cc1cc(O)c(=O)c(O)c2c1C[C@H](C(C)(O)N1CCCCC1)CC2</smiles>

manicol derivative 5 a

HIV RT RNase $\mathrm{H} \mathrm{IC}_{50}=820 \mathrm{nM}$

Cellular Antiviral Activity $\mathrm{EC}_{50}=10.2 \mu \mathrm{M}$

T Cell Cytotoxicity $\mathrm{CC}_{50}=>50 \mu \mathrm{M}$<smiles>CC[Si](=O)CC(C)(O)[C@@H]1CCc2c(c(C)cc(O)c(=O)c2O)C1</smiles>

manicol derivative $5 \mathrm{c}$

HIV RT RNase $\mathrm{H} \mathrm{IC}_{50}=0.24 \mu \mathrm{M}$

Cellular Antiviral Activity = weak activity

T Cell Cytotoxicity $\mathrm{CC}_{50}=10.4 \mu \mathrm{M}$

Figure 12.

Examples of manicol derivatives, along with HIV RT RNase H activity and cellular antiviral and cytotoxicity data. 


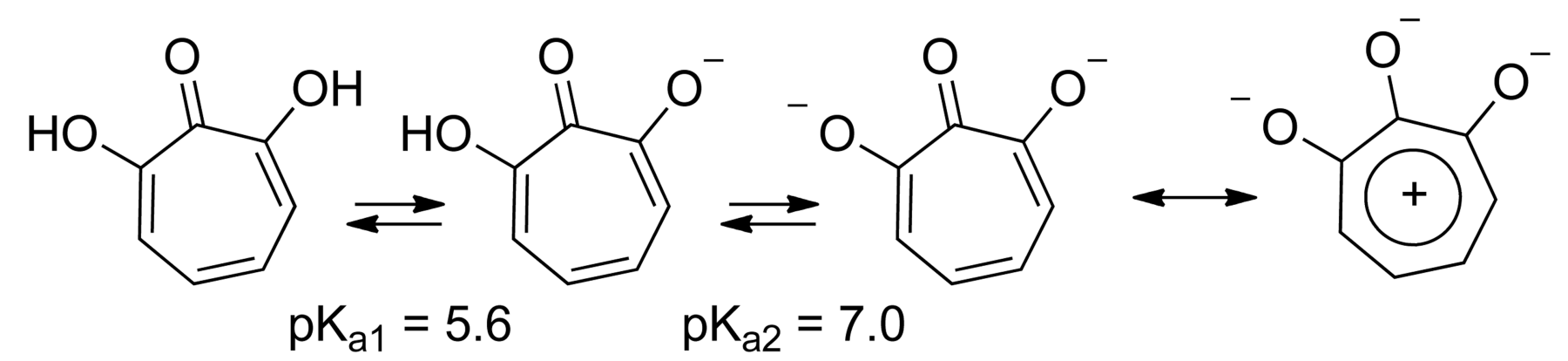

Scheme 1.

Equilibrium constants of a-hydroxytropolone, and tropylium resonance form. 

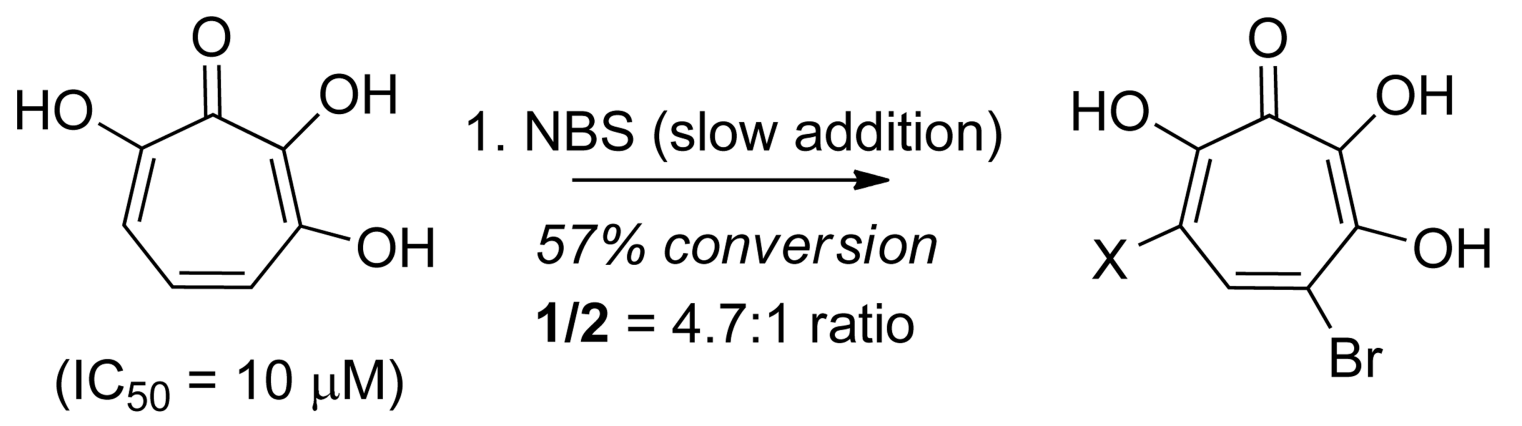

1, $X=H$
$2, X=B r$
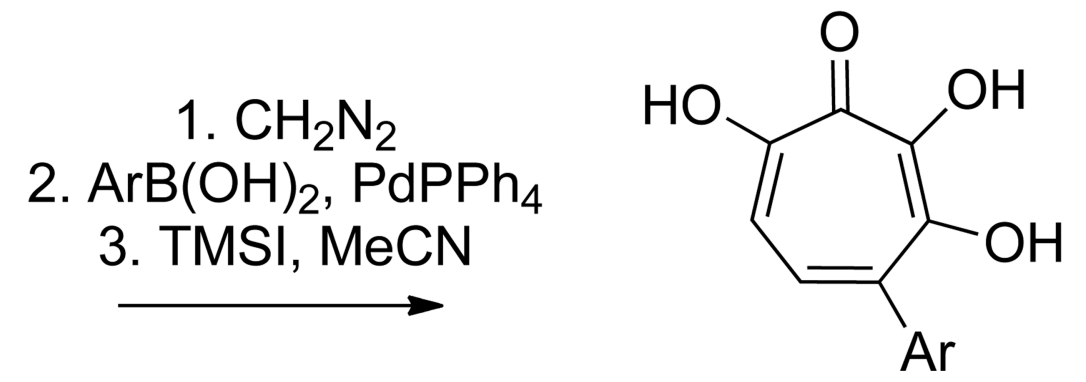
3, $\mathrm{Ar}=4-\mathrm{CNC}_{6} \mathrm{H}_{4}$ $\left(\mathrm{IC}_{50}=4 \mu \mathrm{M}\right)$

Scheme 2.

Method for functionalizing 3,7-dihydroxytropolone, and inhibitory activity against inositol monophosphatase. 
<smiles>O=c1cccc2cc(O)c(O)c(O)c2c1O</smiles>

purpurogallin<smiles>O=C1OC(=O)c2c1cccc(=O)c2O</smiles>

$\mathrm{Br}_{2}, \mathrm{AcONa}$, $\mathrm{AcOH}$<smiles></smiles>

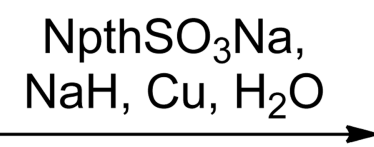<smiles>O=C1OC(=O)c2c1ccc(O)c(=O)c2O</smiles>

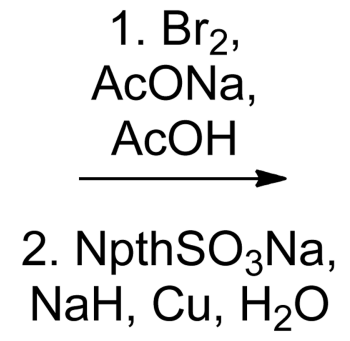

puberulonic acid

Scheme 3.

An example of an oxidation strategy toward aHTs and 3,7-dihydroxytropolones in the synthesis of puberulonic acid. 
<smiles>CCOC(=O)COC(=O)C1=CC(OC)=C(OC)C=C(OC)C1</smiles><smiles>O=C(O)c1cc(O)cc(=O)c(O)c1</smiles>

stipitatic acid $4.5 \%$ yield over 3 steps
1. $\mathrm{Br}_{2} / \mathrm{AcOH}$

2. $\mathrm{KOH} / \mathrm{H}_{2} \mathrm{O}$ $200{ }^{\circ} \mathrm{C}$

Scheme 4.

A cyclopropanation strategy in the total synthesis of stipitatic acid and puberulic acid from 1,2,4-trimethoxybenzene. 
<smiles>c1ccc2c(c1)OCO2</smiles>

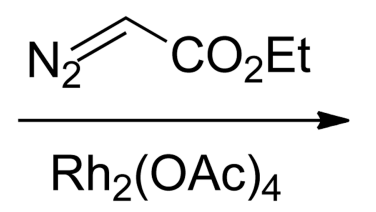<smiles>CCOC(=O)C1C=CC2=C(C=C1)OCO2</smiles>
tetraphenylporphorine,

\section{1,3-benzodioxole}<smiles>CCOC(=O)C1C=CC23CC(C(=O)OCC)C4OC4C2(O1)OC(C)(C)C(C)(C)O3</smiles><smiles>CCOC(=O)c1ccc(O)c(=O)c(O)c1</smiles>

Scheme 5.

Singlet Oxygen oxidation/cobalt-mediated rearrangement to form aHTs from cyclopropanation-generated cyclohexatrienes. 


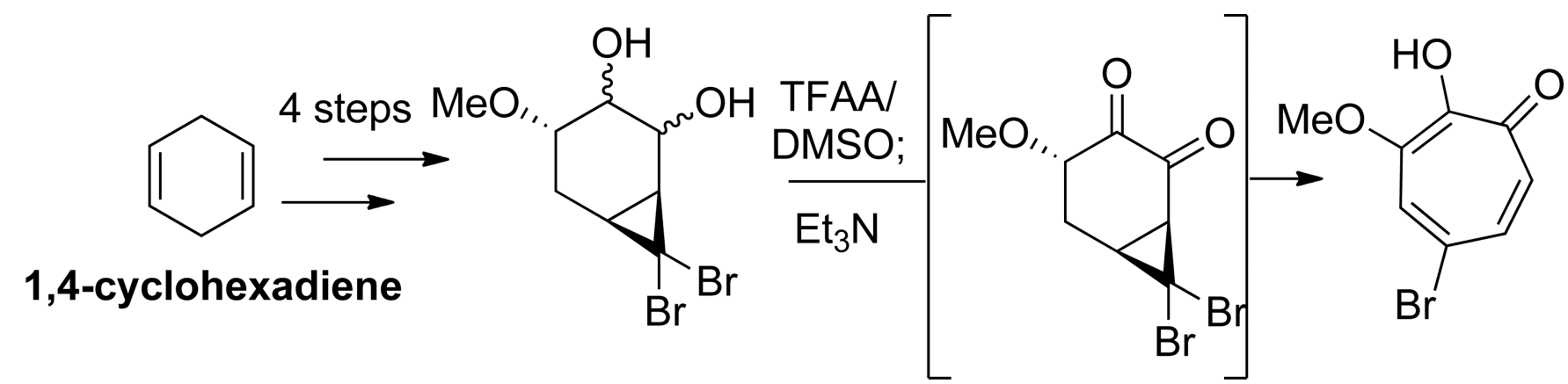<smiles>C=C([AsH2])CCCC(=O)O</smiles><smiles>O=c1c(O)ccc(P)cc1O</smiles>

\section{$\beta$-thujalpicinol}

Scheme 6.

A cyclopropanation/ Grob fragmentation strategy in the synthesis of $\beta$-thujaplicinol from 1,4-cyclohexadiene 


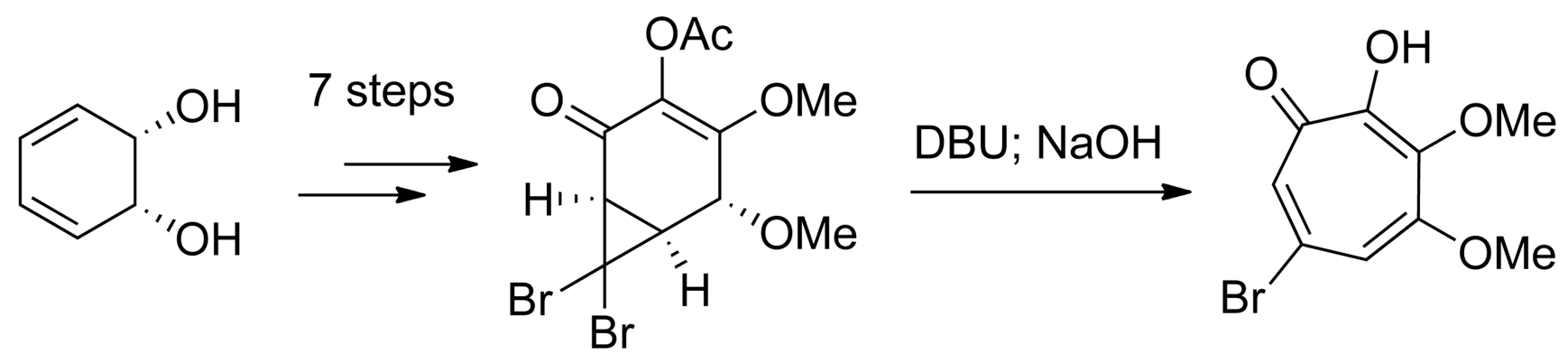<smiles>COc1cc(C(=O)O)cc(=O)c(O)c1O</smiles>
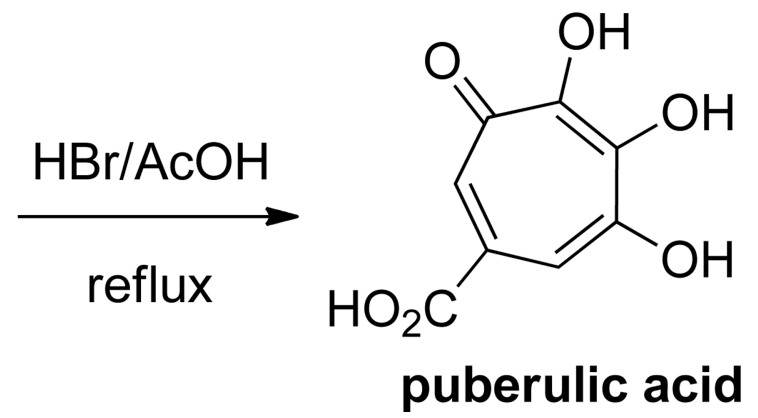

Scheme 7.

A cyclopropanation/Grob fragmentation strategy in the synthesis of puberulic acid 

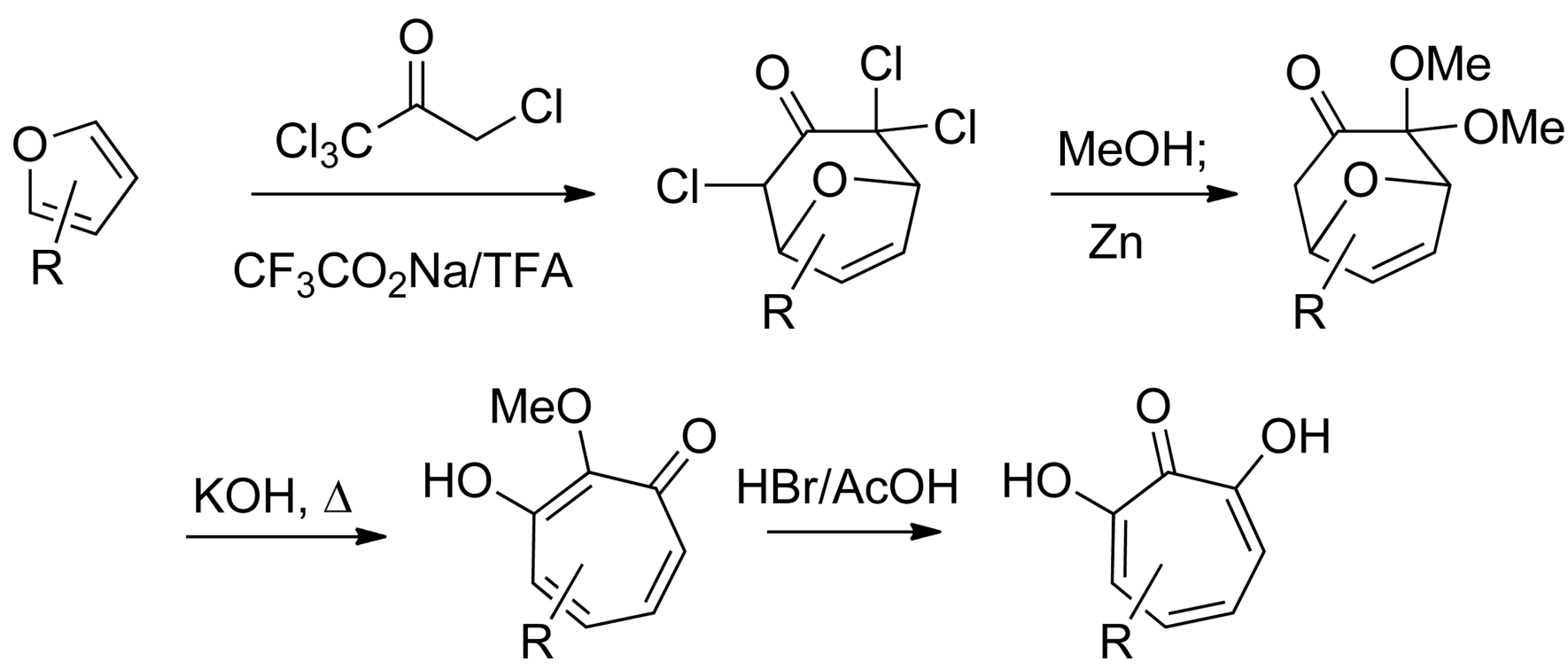

Scheme 8.

[4+3] Cycloaddition approach to a-hydroxytropolones leveraging the ring-opening of 8oxabicyclo[3.2.1]octenes 
<smiles>O=c1cc(CO)occ1O</smiles>

kojic acid<smiles>[R7]c1cc(OC)c(O)c[o+]1</smiles>
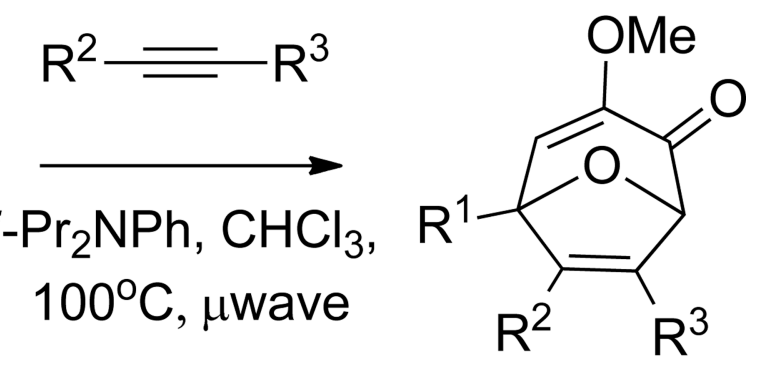

$\mathrm{TfOH}$<smiles>[R]c1cc(OC)c(O)c(=O)c([R])c1[R2]</smiles>

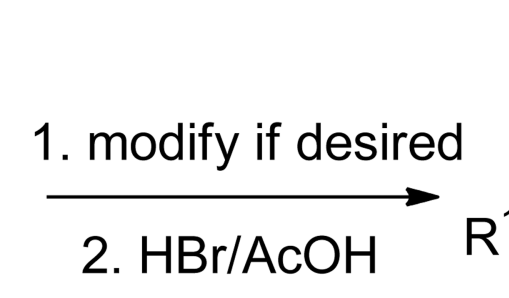<smiles>O</smiles>

( 
<smiles>COC(=N)C=NC(=[W])C(=O)OC</smiles>

$\mathrm{Rh}(\mathrm{II})$ octanoate dimer

$N_{2}$

$\mathrm{N}_{2}$
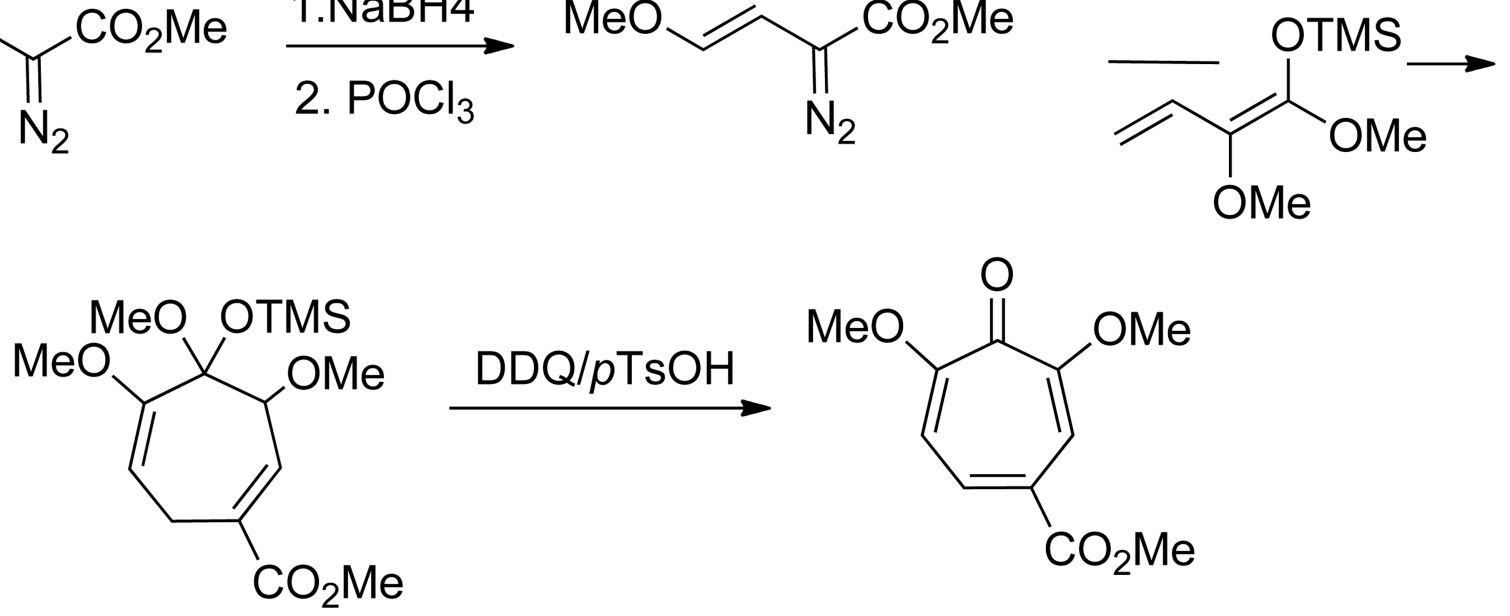

Scheme 10.

A cyclopropanation/Cope rearrangement strategy to highly oxidized tropones. 